\title{
Ekstraksi Gelatin Tulang Ikan Gabus (Channa striata) dengan Variasi Asam yang Berbeda pada Proses Demineralisasi
}

\section{Extraction of Cork Fish Bone Gelatin (Channa striata) with Different Acid Variations in the Demineralization Process}

\author{
Fitra Mulia Jaya ${ }^{1 *}$ dan Neny Rochyani ${ }^{1}$ \\ 'Dosen Program Studi Ilmu Perikanan Fakultas Perikanan Universitas PGRI Palembang \\ *Email: F_Muliajaya@yahoo.co.id
}

\begin{abstract}
Abstrak
Diterima

13 Juni 2020

Palembang merupakan ibu kota Provinsi Sumatera Selatan yang memiliki makanan khas dengan bahan baku utama ikan. Banyak pengusaha pempek yang memanfaatkan daging ikan gabus untuk bahan baku pempek sehingga mengakibatkan banyak sekali limbah tulang ikan gabus, oleh karena itu peneliti memanfaatkan limbah tulang ikan gabus sebagai alternatif bahan baku

Disetujui 14 September 2020 pembuatan agar-agar. Dalam penelitian ini peneliti menggunakan beberapa asam lemah yang berasal dari bahan alami seperti ekstrak jeruk nipis dan ekstrak belimbing wuluh dan sebagai pembanding peneliti menggunakan asam lemah sintetik yaitu asam sitrat yang beredar di pasaran. Tujuan penelitian ini adalah menggunakan beberapa jenis asam dalam proses demineralisasi untuk menghasilkan produksi gelatin yang lebih baik. Penelitian ini menggunakan Rancangan Acak Lengkap, dengan beberapa perlakuan asam dengan dan terdiri dari 3 (tiga) taraf perlakuan, masing-masing perlakuan diulang sebanyak 3 kali. Perlakuan dalam penelitian ini adalah proses demineralisasi dengan penambahan asam sitrat (A1), ekstrak jeruk nipis (A2), dan ekstrak belimbing wuluh (A3). Parameter yang diteliti dalam penelitian ini antara lain: Rendemen Gelatin, Keasaman Gelatin $(\mathrm{pH})$, Kelembaban dan Kandungan Sensorik (warna dan aroma). Data hasil observasi terdekat dianalisis dengan analysis of variance (ANOVA) dan selanjutnya diuji berdasarkan koefisien keanekaragaman. Dari hasil penelitian didapatkan bahwa perlakuan terbaik penggunaan variasi asam adalah gelatin terdemineralisasi menggunakan asam sitrat yang menghasilkan rendemen $6 \%$, kadar air 9,21\%, pH 6, nilai warna kesukaan panelis adalah 4.3 dan aroma 3,8
\end{abstract}

Kata kunci: Asam lemah, Demineralisasi, Gelatin, Tulang ikan

\begin{abstract}
Palembang is the capital city of South Sumatra Province which has special foods which main raw material is fish. Many pempek entrepreneurs use cork fish meat for pempek raw material resulting in abundance of cork fish bone waste, therefore researchers utilize cork fish bone waste as an alternative into raw material in making gelatin. In this study, researchers used several weak acids derived from natural ingredients such as lime extract and starfruit extract and as a comparison researchers used synthetic weak acids namely citric acid in the market. The purpose of this research used several types of acids in the demineralization process to produce better gelatin production. This study used a Completely Randomized Design, with several acid treatments with and consisting of 3 (three) treatment levels, each treatment was repeated 3 times. The treatment in this study was a demineralization process with the addition of citric acid was (A1), lime extract was (A2), and starfruit extract was (A3). The parameters examined in this study include: Gelatin yield, Gelatin acidity $(\mathrm{pH})$,
\end{abstract}


Moisture and Sensory content (color and aroma). Data from proximate observations were analyzed by analysis of variance (ANOVA) and further tested based on the coefficient of diversity. From the results of this study, it was found that the best treatment of using variations in acid was gelatin demineralized using citric acid which produced a yield was $6 \%$, a moisture content was $9.21 \%$, $\mathrm{pH} 6$, the panelist's favorite value of color was 4.3 and aroma 3,8 .

Keyword: Weak acids, Demineralization, Gelatin, Fish bones

\section{Pendahuluan}

Palembang merupakan ibu kota Provinsi Sumatera Selatan yang memiliki makanan khas yang bahan baku utamanya dari ikan. Makanan khas Palembang yang paling terkenal di Indonesia adalah Pempek Palembang. Bahan baku ikan yang sering dipergunakan dalam pembuatan pempek yaitu ikan gabus, ikan tenggiri, ikan sardine dan masih banyak lagi ikan air tawar dan ikan air laut lainnya yang dapat dimanfaatkan. Daging ikan gabus merupakan bahan baku yang paling sering digunakan sebagai bahan baku pembuatan pempek, karena mempunyai kekuatan gel yang baik. Banyaknya pengusaha pempek memanfaatkan daging ikan gabus untuk bahan baku pempek mengakibatkan berlimpahnya limbah tulang ikan gabus. Pemanfaatan limbah hasil perikanan tersebut belum termanfaatkan secara maksimal. Oleh karena itu peneliti memanfaatkan limbah tulang ikan gabus tersebut sebagai suatu alternatif menjadi bahan baku dalam pembuatan gelatin.

Gelatin merupakan suatu protein yang umumnya berasal dari hewan ternak seperti sapi dan babi. Kebutuhan akan gelatin dalam industri pangan non pangan dan obat-obatan sangat pesat, hal ini dapat dilihat pada tahun 2002 produksi gelatin dunia mencapai 270.000 ton (Rodiah et al., 2018). Pembuatan gelatin melalui beberapa proses yang salah satunya yaitu demineralisasi merupakan proses perendaman dalam larutan asam untuk melanjutkan pembengkakan tulang sehingga kolagen yang ada dalam tulang mudah keluar (Amiruddin, 2007).

Berdasarkan penelitian-penelitian sebelumnya, proses demineraliasi telah menggunakan asam lemah dalam produksi gelatin untuk menghasilkan rendemen gelatin lebih banyak. Penggunaan asam dari bahan alami dalam proses demineralisasi untuk mendapatkan gelatin dari tulang ikan masih terbatas, sehingga perlu dilakukan penelitian tentang memanfaatkan beberapa asam lemah yang berasal dari bahan alami seperti ektrak jeruk nipis dan ektrak belimbing wuluh. Serta sebagai pembanding peneliti menggunakan asam lemah sintetik yaitu asam sitrat yang ada dipasaran. Sehingga dapat dibandingkan berapa besar gelatin yang dihasilkan dari bahan-bahan tersebut agar diperoleh bahan ekstrasi yang tepat untuk meningkatkan produksi gelatin.

\section{Bahan dan Metode}

\subsection{Bahan dan Alat}

Bahan yang digunakan adalah tulang ikan Gabus (Channa striata) yang diperoleh dari pasar 26 Soak Bato Palembang, air perasan jeruk nipis, ektrak belimbing wuluh dan asam sitrat. Alat yang digunakan pada penelitian ini adalah oven, pisau, peralatan gelas, neraca analitik, krus porselin, gegep besi, waterbath, ember, aquades, aluminium foil, kertas $\mathrm{pH}$ universal, kertas saring, dan plastik.

\subsection{Metode Penelitian}

Metode penelitian yang digunakan pada penelitian ini yaitu metode eksperimen dengan membandingkan perlakuan penggunaan asam sitrat, jeruk nipis dan belimbing wuluh, dengan perlakuan:

- A1 (penambahan asam sitrat pada proses demineralisasi)

- A2 (penambahan ekstrak jeruk nipis pada proses demineralisasi).

- A3 (penambahan belimbing wuluh pada proses demineralisasi).

\subsection{Prosedur Penelitian}

Penelitian ini dilaksanakan dalam 2 tahap yaitu, tahap pertama persiapan bahan baku serta asam dan tahap kedua ekstrasi gelatin dari tulang ikan gabus yang didemineralisasi dengan beberapa asam.

\subsubsection{Preparasi Bahan baku dan bahan pendukung}

a) Preparasi sampel tulang ikan Tulang ikan Gabus yang didapat dari pasar Soak Batu sebanyak $10 \mathrm{~kg}$ dibersihkan

b) Preparasi asam

Preparasi asam yaitu ekstraksi asam dari jeruk nipis. Preparasi asam diawali dengan pengupasan jeruk nipis, kemudian jeruk nipis dihaluskan dengan blender tanpa ditambahkan air. Selanjutnya ekstrak (sari) buah jeruk nipis disaring untuk memisahkan sari dan ampas. Lalu ekstrak jeruk nipis diukur volume dan memiliki pH 3. 
c) Preparasi asam yaitu ekstraksi asam dari belimbing wuluh. Preparasi asam diawali dengan pencucian belimbing wuluh, kemudian dihaluskan menggunakan blender tanpa penambahan air. Selanjutnya ekstrak sari belimbing wuluh disaring untuk memisahkan sari dan ampas. Lalu ekstrak belimbing wuluh diukur volume dan memiliki $\mathrm{pH} 3$.

d) Persipan Asam sitrat

Asam sitrat yang digunakan adalah dibeli dari toko bahan kimia

\subsubsection{Proses Ekstrasi Gelatin (Syahraeni et al, 2017)}

a) Degreasing: Tulang ikan Gabus yang telah dibersihkan dari sisa-sisa daging dan lemak yang masih menempel (degreasing) yaitu dengan merendam dalam air mendidih selama 30 menit sambil diaduk. Selanjutnya ditiriskan dan dipotong dengan panjang $\pm 2 \mathrm{~cm}$, kemudian dikering anginkan.

b) Demineralisasi: Sebanyak 100 gram bahan baku direndam dengan larutan asam (asam sitrat, ekstrak jeruk nipis, dan belimbing wuluh) dalam wadah plastik tahan asam dengan perbandingan tulang : larutan asam 1:3 (b/v) selama 12 jam hingga menghasilkan osein. Osein dibilas sampai diperoleh $\mathrm{pH}$ netral.

c) Ekstraksi: Osein selanjutnya dimasukkan ke dalam erlenmeyer dan ditambahkan aquadest dengan perbandingan $1: 3(\mathrm{~b} / \mathrm{v})$. Kemudian diekstraksi dalam waterbath pada suhu $70^{\circ} \mathrm{C}$ selama 6 jam. Ekstrak gelatin yang diperoleh, dikeringkan dalam oven, setelah kering kemudian dihaluskan, dihitung rendemennya dan dianalisis. Rendemen diperoleh dari perbandingan berat kering gelatin yang dihasilkan dengan bahan baku.

\subsection{Parameter yang dianalisis}

Parameter yang di analisis dalam penelitian ini adalah rendemen gelatin, derajat keasaman $(\mathrm{pH})$ gelatin, kadar air dan uji sensoris terhadap warna dan aroma gelatin.

\subsection{Analisis Data}

Data yang diperoleh diolah dengan statistik. Pengolahan data dilakukan secara kuantitatif menggunakan teknik pengolahan data analisis parametrik dan analisis statistik non paramaetrik.

1. Analisis Statistik Parametrik Analisis statistik parametrik dilakukan untuk menganalisis data dari hasil analisa rendemen gelatin, derajat keasaman, kadar air.

2. Analisa Statistik Non Parametrik

Data uji sensoris dengan uji hedonik dianalisa dengan menggunakan uji model Friedman-Connover.

\section{Hasil dan Pembahasan}

\subsection{Rendemen Gelatin}

Pengukuran nilai rendemen dilakukan untuk dapat mengetahui efektifitas dalam proses pengolahan gelatin. Menurut Rodiah et al. (2018) bahwa pengukuran nilai rendeman didapatkan dari hasil membandingkan berat bahan gelatin yang telah kering dengan berat bahan baku yang digunakan. Pada penelitian ini, peneliti menggunakan beberapa asam lemah dalam mendemineralisasi bahan baku menjadi osein. Adapun asam lemah yang digunakan adalah asam sitrat, asam dari buah jeruk nipis dan asam dari buah belimbing wuluh sebanyak $5 \%$. Hasil pengukuran rata-rata nilai rendemen gelatin pada penelitian ini disajikan pada Gambar 1.

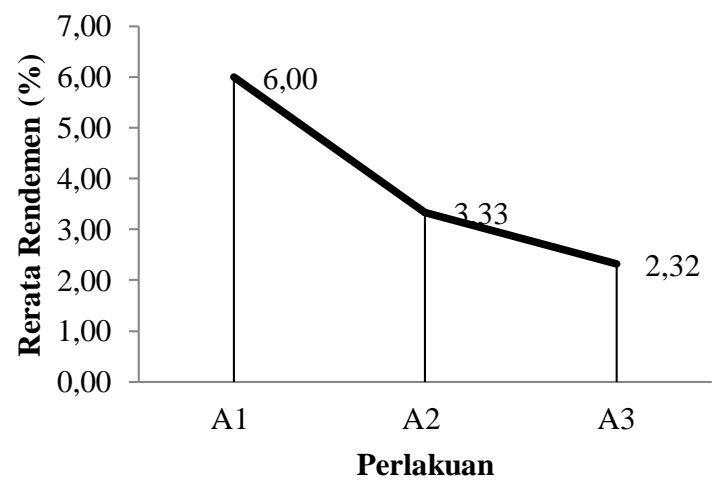

Gambar 1. Rerata nilai rendemen gelatin tulang ikan Gabus (C. Striata)

Keterangan : Perlakuan A1 (penambahan asam sitrat pada proses demineralisasi), A2 (penambahan ekstrak jeruk nipis), dan A3 (penambahan ekstrak belimbing).

Grafik diatas menunjukkan rerata nilai rendemen gelatin dari tulang ikan gabus dengan perlakuan penambahan asam pada proses demineralisasi. Nilai rerata rendemen berkisar antara 2,32\% sampai dengan $6 \%$. 
Nilai rendemen tertinggi terdapat pada perlakuan A1 dan nilai terendah terdapat pada perlakuan A3. Rerata nilai rendemen yang dihasilkan masih rendah, hal ini dikemungkinan asam yang digunakan dalam mendemineralisasi bahan baku tulang ikan gabus merupakan asam lemah.

Hasil analisis sidik ragam, menunjukkan bahwa perlakuan penambahan asam lemah pada proses demineralisasi tulang ikan gabus berbeda sangat nyata terhadap nilai rendemen gelatin yang dihasilkan pada taraf 5\%. Koefisien keragaman yang dihasilkan sebesar 17,86\% sehingga uji lanjut yang digunakan yaitu uji lanjut BNJD. Hasil analisis uji lanjut BNJD disajikan pada Tabel 1. berikut.

Tabel 1. Hasil Uji Lanjut BNJD Rendemen Gelatin

\begin{tabular}{|l|c|c|c|c|}
\hline \multirow{2}{*}{ Perlakuan } & \multirow{2}{*}{ Rerarta } & \multicolumn{2}{|c|}{ beda riel pada jarak $p$} & $\begin{array}{c}\text { BNJD } \\
5 \%\end{array}$ \\
\cline { 3 - 5 } & & 2 & 3 & 0,05 \\
\hline $\begin{array}{l}\text { A3(Belimbing } \\
\text { Wuluh) }\end{array}$ & 2,32 & - & & a \\
$\begin{array}{l}\text { A2(Jeruk } \\
\text { Nipis) }\end{array}$ & 3,33 & 1,01 & - & a \\
$\begin{array}{l}\text { A1(Asam } \\
\text { Sittrat) }\end{array}$ & 6,00 & 2,67 & 3,68 & b \\
\hline
\end{tabular}

Keterangan : huruf superscript (a dan b) yang berbeda pada kolom yang sama menunjukkan perbedaan nyata antar perlakuan $(\mathrm{P}<0,05)$.

Tabel 1 menunjukkan bahwa perlakuan asam lemah pada proses demineralisasi berpengaruh nyata terhadap rendemen gelatin yang dihasilkan. Rendemen yang dihasilkan perlakuan A1 dan A2 berbeda nyata dengan perlakuan A3. Sedangkan perlakuan A2 dan perlakuan A1 tidak berbeda nyata.

Berdasarkan hasil uji lanjut BNJD, perlakuan penggunaan asam sitrat komersial yang diperoleh pada waktu proses demineraliasi berpengaruh nyata terhadap rendemen gelatin yang dihasilkan. Hal ini disebabkan, asam sitrat sintetik yang digunakan lebih murni $\mathrm{C}_{6} \mathrm{H}_{8} \mathrm{O}_{7}$ dibandingkan asam yang berasa dari jeruk nipis dan belimbing wuluh sehingga efektivitas dalam mendemineraliasi tulang ikan menjadi osein lebih tinggi. Namun, secara umum rendemen gelatin yang dihasilkan lebih rendah karena asam yang digunakan dalam penelitian ini adalah asam lemah sehingga aktifiktas larutan asamnya tidak maksimal melonggarkan ikatan rantai kolagen maupun ikatan silang antar kolagen (Ramadani, 2014). Selain itu, rendahnya rendemen gelatin juga kemungkinan disebabkan suhu yang digunakan dalam proses ekstraksi osein menjadi gelatin terlalu tinggi yaitu $90^{\circ} \mathrm{C}$.

\subsection{Derajat Keasaman ( $p H)$ Gelatin}

Pengukuran nilai $\mathrm{pH}$ larutan gelatin penting dilakukan, karena nilai $\mathrm{pH}$ larutan gelatin mempengaruhi sifatsifat gelatin yang lainnya seperti viskositas dan kekuatan gel (Astawan et al., 2002). Menurut GMIA (2001), nilai $\mathrm{pH}$ gelatin berkisar antara 5.0 - 7.5. Gelatin dengan nilai $\mathrm{pH}$ netral akan bersifat stabil dan penggunaannya akan lebih luas. $\mathrm{pH}$ gelatin berdasarkan standar mutu gelatin secara umum diharapkan mendekati $\mathrm{pH}$ netral $(\mathrm{pH}$ 7). Nilai $\mathrm{pH}$ gelatin berhubungan dengan proses yang digunakan untuk membuatnya. Proses asam cenderung menghasilkan nilai $\mathrm{pH}$ rendah, sedangkan proses basa akan memiliki kecenderungan menghasilkan nilai $\mathrm{pH}$ yang tinggi. Gelatin dengan nilai $\mathrm{pH}$ netral cenderung lebih disukai, sehingga proses penetralan memiliki peran penting untuk menetralkan sisa-sisa asam maupun sisa-sisa basa setelah dilakkan perendaman (liming) (Hinterwaldner, 1977). Hasil pengukuran rata-rata nilai pH gelatin pada penelitian ini disajikan pada Gambar 2.

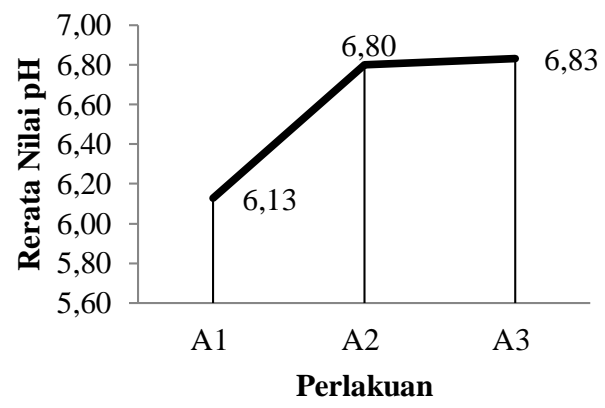

Gambar 2. Rerata nilai pH gelatin tulang ikan Gabus (C. striata)

Keterangan : Perlakuan A1 (penambahan asam sitrat pada proses demineralisasi), A2 (penambahan ekstrak jeruk nipis), dan A3 (penambahan ekstrak belimbing).

Gambar diatas menunjukkan rerata nilai $\mathrm{pH}$ gelatin dari tulang ikan gabus dengan perlakuan penambahan asam pada proses demineralisasi. Nilai rerata $\mathrm{pH}$ berkisar antara 6,13\% sampai dengan 6,83\%. Nilai $\mathrm{pH}$ tertinggi terdapat pada 
perlakuan A3 dan nilai rendemen yang terendah terdapat pada perlakuan A1. Hasil anilisis sidik ragam, menunjukkan bahwa perlakuan penambahan asam lemah pada proses demineralisasi tulang ikan Gabus tidak berbeda nyata terhadap nilai $\mathrm{pH}$ gelatin yang dihasilkan sehingga tidak dilakukan uji lanjut.

\subsection{Kadar air Gelatin}

Air merupakan salah satu unsur yang penting di dalam bahan pangan karena keberadaannya di dalam makanan dapat mempengaruhi fisik dan citra rasa dari bahan pangan tersebut. Selain itu, tinggi rendahnya kandungan air dalam suatu bahan pangan akan mempengaruhi tekstur dari bahan pangan (Winarno dalam Tridhar, 2016). Kadar air dalam suatu bahan pangan di hasilkan dari berat bahan awal dan berar bahan akhir. Hasil pengukuran rata-rata nilai persentase kadar air gelatin pada penelitian ini disajikan pada Gambar 3.

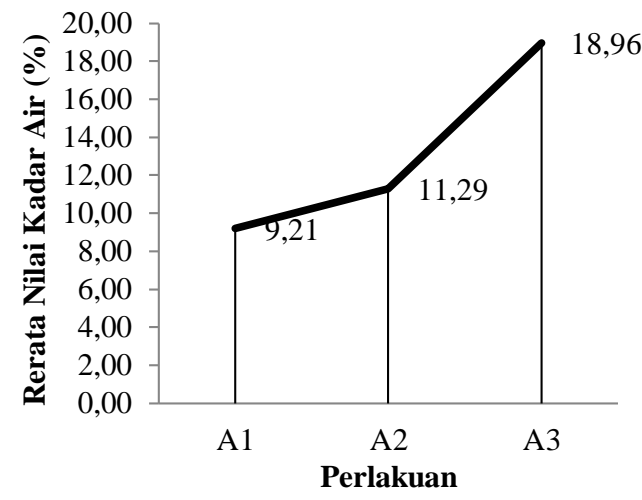

Gambar 3. Rerata nilai persentase kadar air gelatin tulang ikan gabus (C. Striata)

Keterangan : Perlakuan A1 (penambahan asam sitrat pada proses demineralisasi), A2 (penambahan ekstrak jeruk nipis), dan A3 (penambahan ekstrak belimbing).

Gambar diatas menunjukkan rerata nilai kadar air gelatin dari tulang ikan gabus dengan perlakuan penambahan asam pada proses demineralisasi. Nilai rerata kadar air berkisar antara 9,21\% sampai dengan 18,96\%. Nilai kadar air tertinggi terdapat pada perlakuan A3 dan nilai rendemen yang terendah terdapat pada perlakuan A1. Hasil anilisis sidik ragam, menunjukkan bahwa perlakuan penambahan asam lemah pada proses demineralisasi tulang ikan Gabus berpengaruh nyata terhadap kadar air gelatin yang dihasilkan. Koefisien keragaman yang dihasilkan sebesar 7,81\% sehingga uji lanjut yang digunakan yaitu uji lanjut Beda Nyata Terkecil (BNT). Hasil analisis uji lanjut BNT disajikan pada Tabel 2. berikut.

Tabel 2. Hasil Uji Lanjut BNT Kadar Air Gelatin

\begin{tabular}{|l|c|c|}
\hline \multicolumn{1}{|c|}{ Perlakuan } & Rerata & $\begin{array}{c}\text { BNT 5\% } \\
\text { Notasi }=2,05\end{array}$ \\
\hline A1 (Asam Sitrat) & 9,21 & a \\
A2 (Jeruk Nipis) & 11,29 & b \\
A3 (Belimbing Wuluh) & 18,96 & $\mathrm{c}$ \\
\hline
\end{tabular}

Keterangan : hruruf superscript $(\mathrm{a}, \mathrm{b}$ dan $\mathrm{c}$ ) yang berbeda pada kolom yang sama menunjukkan perbedaan nyata antar perlakuan $(\mathrm{P}<0,05)$

Tabel 2 menunjukkan bahwa perlakuan asam lemah pada proses demineralisasi berpengaruh nyata terhadap kadar air gelatin yang dihasilkan. Kadar air yang dihasilkan perlakuan A3 berbeda nyata dengan perlakuan A2 dan sangat berbeda nyata dengan perlakuan A3. Kadar Air gelatin tertinggi terdapat pada perlakuan asam dari belimbing wuluh. Adanya peningkatan kadar air salah satunya dipengaruhi pH dari gelatin itu sendiri. Gelatin dengan suasana yang lebih asam akan kehilangan banyak air dan memilki kadar air terendah (Arifiansyah et al., 2014). Kadar air pada gelatin menurut Norland Product yang merupakan standar mutu gelatin untuk industri farmasi (2003), kadar air gelatin maksimal 14\% oleh karena itu gelatin yang didemineralisasi menggunakan asam sitrat dan jeruk nipis masih masih sesuai standar yang ditetapkan yaitu 9-11,29\%.

\subsection{Uji Organoleptik Gelatin}

Uji organoleptik merupakan salah satu faktor penting untuk mengukur tingkat kesukaan atau penerimaan konsumen terhadap suatu produk (Said et al, 2011). Uji organoleptik memiliki hubungan erat dengan mutu produk karena berhubungan langsung dengan selera konsumen (Soekarto dalam Setiawati, 2009). Parameter dalam pengujian secara organoleptik meliputi pengamatan terhadap warna dan aroma/bau. Uji organoleptik pada penelitian ini dilakukan pada gelatin dari tulang ikan gabus menggunakan uji hedonik yang melibatkan 10 orang panelis. 


\subsection{Uji kesukaan terhadap warna}

Warna merupakan parameter utama yang menentukan tingkat penerimaan konsumen terhadap suatu produk. Penelitian secara subyektif dengan penglihatan masih sangat menentukan dalam pengujian organoleptik warna (Fatimah, 2008). Hasil penilaian sensoris menggunakan uji hedonik terhadap warna gelatin pada penelitian ini disajikan pada Gambar 4 .

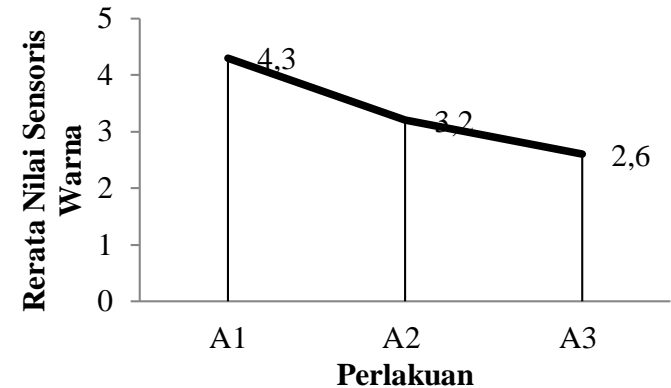

Gambar 4. Grafik rerata kesukaan panelis terhadap warna gelatin tulang ikan Gabus (C. Striata)

Keterangan : Perlakuan A1 (penambahan asam sitrat pada proses demineralisasi), A2 (penambahan ekstrak jeruk nipis), dan A3 (penambahan ekstrak belimbing).

Grafik diatas menunjukkan rerata tingkat kesukaan panelis terhadap warna gelatin dari tulang ikan gabus dengan perlakuan penambahan asam pada proses demineralisasi. Rerata nilai warna berkisar antara 2,6 sampai dengan 4,3. Nilai kesukaan panelis terhadap warna gelatin tertinggi terdapat pada perlakuan A1 dan nilai kesukaan panelis yang terendah terdapat pada perlakuan A3. Hasil uji Friedman Connover menunjukkan bahwa perlakuan asam lemah pada proses demineralisasi tulang ikan gabus berpengaruh nyata terhadap warna gelatin yang dihasilkan. Nilai $\mathrm{T}=15,92308$ lebih besar dari $\mathrm{F}$ tabel $(\mathrm{F}$ Tabel $(\mathrm{K} 1=2, \mathrm{~K} 2=18)=3,55$. Hasil uji lanjut kesukaan panelis terhadap warna disajikan pada Tabel 3. berikut.

Tabel 3. Hasil Uji Lanjut Friedman connover terhadap warna gelatin

\begin{tabular}{|c|c|c|c|}
\hline PERLAKCAN & RERATA & PANGKAT & Notasi=6.10 \\
\hline A3 (Belimbing Wuldh) & 2,60 & 15,0 & A \\
\hline A2 (tenik:Nipis) & 3,20 & 19,0 & A \\
\hline Al (Asam Sitrat) & 4,30 & 27,0 & B \\
\hline
\end{tabular}

Keterangan : huruf superscript (a dan b) yang berbeda pada kolom yang sama menunjukkan perbedaan nyata antar perlakuan $(\mathrm{P}<0,05)$.

Tabel 3 menunjukkan bahwa perlakuan asam lemah pada proses demineralisasi berpengaruh nyata terhadap kesukaan warna gelatin yang dihasilkan. Tingkat kesukaan yang dihasilkan perlakuan A1 berbeda nyata dengan perlakuan A2 dan perlakuan A3. Secara umum warna produk gelatin yang dihasilkan dengan proses dimineraliasi yang berbedan berkisar antara agak suka dan suka. Tingkat kesukaan panelis tertinggi yaitu pada warna gelatin yang proses demineraliasinya menggunakan asam sitrat hal ini dikarenakan warna dari gelatin memiliki warna yang cerah dibandingkan dengan gelatin yang diproses dengan asam dari jeruk nipis dan asam dari belimbing wuluh.

\subsection{Uji kesukaan terhadap aroma}

Hasil penilaian sensoris menggunakan uji hedonik terhadap aroma gelatin pada penelitian ini disajikan pada Gambar 5.

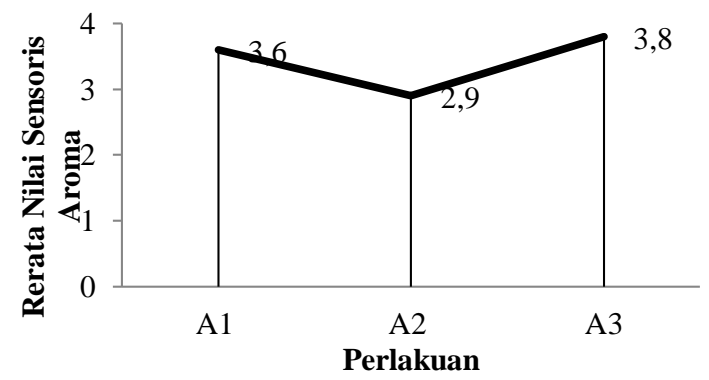

Gambar 5. Grafik rerata kesukaan panelis terhadap aroma gelatin tulang ikan gabus (C. Striata)

Keterangan : Perlakuan A1 (penambahan asam sitrat pada proses demineralisasi), A2 (penambahan ekstrak jeruk nipis), dan A3 (penambahan ekstrak belimbing). 
Gambar diatas menunjukkan rerata tingkat kesukaan panelis terhadap aroma gelatin dari tulang ikan gabus dengan perlakuan penambahan asam pada proses demineralisasi. Rerata nilai aroma berkisar antara 2,9 sampai dengan 3,8. Nilai kesukaan panelis terhadap aroma gelatin tertinggi terdapat pada perlakuan A3 dan yang terendah terdapat pada perlakuan A2. Hasil uji Friedman Connover menunjukkan bahwa perlakuan asam lemah pada proses demineralisasi tulang ikan gabus tidak berpengaruh nyata terhadap tingkat kesukaan panelis terhadap aroma gelatin yang dihasilkan. Nilai $\mathrm{T}=2,19403$ lebih besar dari $\mathrm{F}$ tabel $(\mathrm{F}$ Tabel $(\mathrm{K} 1=2, \mathrm{~K} 2=18)=$ 3,55. Maka tidak dilakukan uji lanjut.

\section{Kesimpulan}

1. Perlakuan beberapa asam lemah pada proses demineralisasi tulang ikan gabus berpengaruh nyata terhadap rendemen gelatin yang dihasilkan.

2. Perlakuan beberapa asam lemah pada proses demineralisasi tulang ikan gabus berpengaruh nyata terhadap kadar air gelatin yang dihasilkan dan tidak berpengaruh nyata pada $\mathrm{pH}$.

3. Perlakuan beberapa asam lemah pada proses demineralisasi tulang ikan gabus juga berpengaruh nyata terhadap parameter organoleptik yaitu warna dan tidak berpengaruh nyata terhadap aroma.

4. Perlakuan terbaik terdapat pada perlakuan A1 dengan hasil rendemen 6\%, kadar air 9,21\%, $\mathrm{pH} 6$, dan nilai kesukaan panelis terhadap warna sebesar 4,3 dan aroma 3,8.

\section{Saran}

Perlu dilakukan lanjutan menggunakan asam kuat untuk membandingkan penggunaan asam lemah dan asam kuat dalam proses demineraliasi tulang ikan gabus terhadap kualitas produksi gelatin. selain itu, Perlu dilakukan penelitian lebih lanjut tentang proses ekstraski dengan suhu lebih tinggi yaitu dibawah $90^{\circ} \mathrm{C}$.

\section{Referensi}

Amiruddin, M. 2007 Pembuatan dan Analisis Karakteristik Gelatin dari Tulang Ikan Tuna (Thumus albacareas). Skripsi. Institut Prtanian Bogor. Bogor.

Arifiansyah, M., E. Wulandari, dan H. Cahirunnisa. 2015. Karakterisitk Kimia Nilai Kesukaan Keju Segar Dengan Penggunaan Koagulasi Jus Jeruk Nipis, Jeruk Lemon dan Asam Sitrat. Jurnal Unpad. 4(1).

Astawan, M., P. Hariyadi, dan A. Mulyani. 2002. Analisis Sifat Rheologi Gelatin dari Kulit Ikan Cucut. Jurnal Teknologi dan Industri Pangan, 13(1): 38-46

Fatimah, D. 2008. Efektivitas Penggunaan Asam Sitrat dalam Pembuatan Gelatin Tulang Ikan Bandeng (Chanos chanos Forskal). Skripsi. Malang: Jurusan Kimia Fakultas Sains dan Teknologi Universitas Islam Negeri Malang

Hinterwaldner, R. 1977. Technology of Gelatin Manufacture. In Ward A.G. and Courts, A. (eds.). The Science and Technology of Gelatin. Academic Press, New York. 315 pp.

Ramadani, D. 2014. Pengaruh Perbedaan Jenis Asam dan Waktu Demineralisasi pada Nilai Rendemen dan Sifat Fisiko Kimia Gelatin Tulang Sapi Bali. Skripsi. Fakultas Peternakan, Univ. Hasanuddin. Makasar.

Rodiah, S., Mariyamah, R. Ahsanunnisa, D. Erviana, F. Rahman, dan A.W. Budaya. 2018. Pemanfaatan Limbah Tulang Ikan Tenggiri Sebagai Sumber Gelatin Halal Melalui Hidrolisis Larutan Asam dengan Variasi Rasio Asam. Jurnal Ilmu Kimia dan Terapan. 2(1): 34-42.

Said, M.I., T. Suharjono, E. Yuny, dan F. Achmad. 2011. Karakteristik Gelatin Kulit Kambing yang Diproduksi Melalui Proses Asam dan Basa. Jurnal Agritech. 31(3): 190-100.

Setiawati, I.H. 2009. Karakterisasi Mutu Fisika Kimia Gelatin Kulit Ikan Kakap Merah (Lutjanus Sp.) Hasil Proses Perlakuan Asam. Skripsi. Bogor: Program Studi Teknologi Hasil Perikanan Fakultas Perikanan dan Ilmu Kelautan Institut Pertanian Bogor.

Syahraeni, H. Anwar, dan Hasri. 2017. Pengaruh Konsentrasi Asam Sitrat dan Waktu Demineralisasi pada Perolehan Gelatin dari Tulang Ikan Kakap Merah (Lutjanus sp). Journal Analit :Analytical and Environment Chemistry. 2(1).

Tridhar, N.A. 2016. Perbandingan Produksi Kolagen dari Sisik dan Tulang Ikan Gurami (Osphronemus gouramy) Secara Kimia Dan Enzimatis. Skripsi. Program Studi Teknologi Pangan. Fak. Teknik. Universitas Pasundan. Bandung. 